\title{
Ageism and Disharmonizing: What Can Civic Education Do?
}

\author{
Yasnita Yasnita $^{1, *}$, Karim Suryadi ${ }^{2}$, Dasim Budimansyah ${ }^{2}$, Udin S Winataputra ${ }^{2}$ \\ ${ }^{1}$ Department of Pancasila and Citizenship Education, Faculty of Social Science, Universitas Negeri Jakarta, Indonesia \\ ${ }^{2}$ Department of Citizenship Education, Faculty of Social Studies Education, Universitas Pendidikan Indonesia, Indonesia
}

Received November 28, 2019; Revised January 6, 2020; Accepted January 13, 2020

Copyright $\odot 2020$ by authors, all rights reserved. Authors agree that this article remains permanently open access under the terms of the Creative Commons Attribution License 4.0 International License

\begin{abstract}
The increment of elderly population in the world has impacted on some aspects of human life, namely culture, politic and economy. This article discusses the phenomenon of ageism in society as a stereotype against elderly. The emergence of this view triggers the appearance of age discrimination, where the generations are socially divided, that leads to social disharmony. This phenomenon was studied from the perspective of Civic Education by using phenomenology study approach. The data were collected by interviewing 32 informants, observing some nursing homes and public places, doing library research, and surveying 466 respondents. This study was conducted in three provinces in Indonesia, namely DKI Jakarta, West Java and Yogyakarta. This study reveals that Global citizenship has not yet reached population ageing issue; and there is a gap of communication between young people and elderly that impacts on their mindset, communication pattern, and even triggers labeling given by young people to elderly, and vice versa. Thus, this study concludes that as the elderly population increases, ageism becomes a cultural challenge that should be faced and solved to maintain a harmonious relation among generations. Anti-ageism is recommended to be one of crucial issues that should be incorporated, discussed and developed in Civic Education and it is also suggested to be inclusive education program plan.
\end{abstract}

Keywords Ageism, Civic Education, Disharmonizing

\section{Introduction}

Getting older is a natural process that will be experienced by every human. For a long time, in society, people believe that 'getting older' is a condition where human feel weaker, unhealthy, and unproductive. They also believe that this condition becomes one of challenges and even problems for family and society. This perception has been inherited by the society in the entire world, which is then so-called ageism. Ageism is manifested in a set of beliefs, norms, attitudes, values and actions used to justify prejudice and stereotype elderly. Ironically, ageism seems to be part of legal culture of society. One of the examples of ageism is Thalaikootai, a tradition of 'killing' elderly. This tradition has been conducted through various rituals and has been inherited from generation to generation. Currently, this culture has been prohibited to protect human rights. However, it is still found that some families keep conducting this tradition to the elderly. In 2014, The National Commission for Elderly reported that a discrimination that has been experienced by elderly is mostly done by their family (children and siblings), both verbal and non-verbal.

WHO (2019) affirms that ageism is prejudice, discrimination and stereotyping addressed to people because of their age, and is a hurtful treatment for it could trigger the elderly to feel worthless, helpless, neglected from work environment, restricted from social service or treatment, and to experience discrimination in the media that marginalize and deny elderly to join their communities. As an example, a media states that “.... Although she is no longer young, $X$ still looks fresh and beautiful" or "... in his age which is no longer young, Y still looks handsome". These sentences seem to claim that age could limits one's beauty or handsomeness, prowess and physical healthy. An elderly states that some television programs portray elderly as human who are in a complex situation of life. It is also supported by a statement expressed by an elderly from Moldova stating that elderly is represented as people who need help and are worthless (International, 2015).

Discrimination towards elderly also occurs at work environment. Generally, companies only accept employee who are still in productive age and limit the age of the job 
applicants for a maximum of 35 or 40 years. Tirto.id (accessed in 20 February, 2019) released an article entitled "Age Discrimination at Work Environment Complicates Job Applicants'. This article, written by Joan Aurelia, argues that people over the age of 40 are stereotyped to be stubborn, arrogant, unable to adapt and not interested to learn new things. Some companies also claim that people with a long working experience tend not to be managed, controlled or led by young people. The discrimination triggers the applicants to be pessimism and withdraw themselves from their social environment. Moreover, the treatment of the community that does not support them makes them more frustrated.

Ageism is a discriminatory treatment that is socially accepted and tolerated, that becomes a serious issue (Robertson, 2017). Numerous studies have proved that ageism has negative effects on human life. Lyons, et.al., (2017) found that ageism can cause mental damage such as depression, anxiety, stressful, and ultimately can impact on their immune system. Ageism leads to marginalization towards elderly in their community and has negative impacts on their health and welfare.

Ageism is an ideology that becomes a powerful tool to manifest age discrimination (disharmony). Ageism spread and grow with habits or culture in the community. Its existence is getting stronger because it is constructed along with the culture and habit itself. Ageism has been less popular than the other issues such as issues of gender, radicalism or fundamentalism. To prevent and stop ageism, it is not merely by doing campaign and various other appeals. Ageism spreads and develops massively; therefore, to reduce this phenomenon, a systematic, planned and massive movement is called for.

By considering the current demographic transition with population in the entire world that rapidly ages, a real action needs to create positive effects on individuals and society. In 2016, WHO (World Health Organization) received the mandate to coordinate the global campaign to prevent ageism. The global campaign will provide a platform to change attitudes towards age and aging and to work together to build a world that is inclusive of all ages. These changes are essential to ensure the health and welfare in our life and will only be possible through collective action.

1 October is the International Elderly Day. In 2019, the United Nations sets a theme "The Journey to Age Equality". Indeed, this is a theme that supports the anti-ageism campaign that is being intensified by WHO and other agencies in the world. To complement what is being fought by the UN, in this study, researcher offers ideas to take concrete, more massive, planned and systematic actions, namely, by utilizing educational institutions, since according to the findings of the RSPH (The Royal Society for Public Health) and Calouste Gulbenkian Foundation ageism had begun to grow since childhood, i.e. since around 6 years old (Nainggolan, 2018).
Formal education in schools, becomes "kawah candradimuka" (a term used to explain a place to learn, grow and improve our character to be a better individual) in instilling the inclusive values in the next generation so that they can live harmoniously despite the diversities. Subject that can be used as the foundation to do this task is Civic Education. The question that arises then is, what can be done by Civic Education in anticipating and preventing further, massive and rapid spread of ageism?

In the long-term, Anti-ageism is proposed to be one of the issues that must be involved, discussed and developed in Civic Education and become an inclusive education program plan. The inclusiveness brings the idea of how people can accept and live in diversity; religion, political choice, race, colour, ethnicity, and age.

\section{Literature Review}

\subsection{What is Ageism?}

The notion of ageism was firstly articulated by Robert Neil Butler through her academic work entitled "Age-ism: Another form of bigotry". He discovers this notion in a detail description in which he pictures ageism by focusing on a discriminatory treatment to elderly (Butler, 1969). More specifically, Butler defines that ageism is a systematic stereotyping process or discriminatory treatment treated to an individual or a group of elderly, and value the elderly as a population that is different from other populations. He considers that ageism is manifested in "various phenomena at both individual and institution levels" stereotype and myth, underestimate and aversion, ignorance, and discriminatory treatment at home, work, and other public places and services. The most common age stereotype is done towards poor health, disability or loss of certain ability, and death.

The definition of ageism is not superficial; therefore, in some literature reviews, the scholars agree to formulate conceptual clarification of age that is more understandable and specific in order to ease the scholars, experts, and researchers to study more deeply and comprehensively the concept of ageism (Snellman, 2016). On the other side, aging and anti-aging have offered a big business opportunity such as aesthetic services, day care, legal advocacy, hormone therapy, or sale of food and beverage products that can slow down the aging process that is widely believed as a period when elderly loses his or her appeal. This is one of the significant impacts of stereotypes on parents.

Referring to other studies, stereotype also impacts on one's mental health when they feel no longer cared for, neglected, and even considered as a second-class population compared to younger people who are more productive, healthier and physically stronger. Lyons, et.al. (2017) accomplished a national survey in Australia that involved 2137 elderly (over 60 years). The survey reveals 
that the elderly has suffered mental health issue such as depression, anxiety, and stressful (Lyons, et al., Experiences of Ageism and the Mental Health of Older Adults, 2017).

Butler explains that ageism will be systematically embedded and this condition can hinder people's objectivity and further will affect individual decision (micro level), institution or community decision (meso level), and state decision in providing services for elderly (macro level). Here is the cycle of the effects of ageism designed based on Butler's theory.

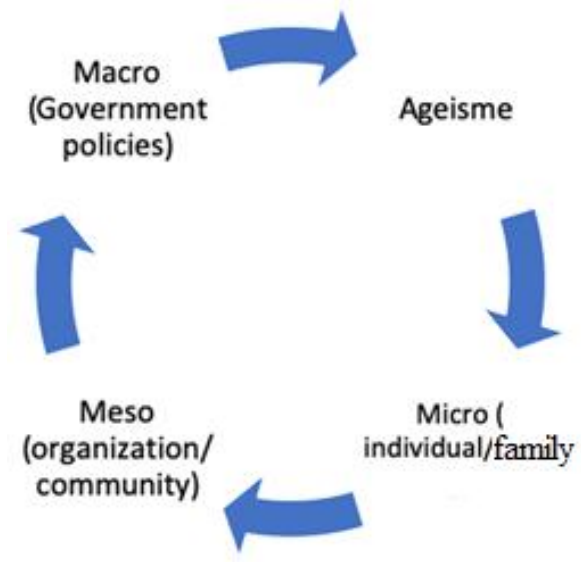

Source : Yasnita (2019)

Figure 1. Cycle of the Effects of Ageism (Designed by writer based on Butler's theory, 1969)

Then why are elderly neglected? This is because of the other ages, namely young people who are treated well with valued norm and become respected group. When it happens, the elderly will slowly withdraw him or herself from their society (disengagement theory). Disengagement theory defines aging process as a period of separation between the "young" and "old" people that divides (discriminates) the generations and leads them to disharmony conditions.

Researchers conclude that ageism is a problematic issue for generation sustainability (Kelchner ,2000 \& Butler, 1969) that impacts on the elderly, society, and elderly services (Kelchner, 2000). This problem becomes a serious challenge for population in the entire world that is ageing. WHO responds this condition by proposing anti-ageism campaign, and since 2016 it is mandated to manage the global campaign against ageism.

Preventing and combating ageism is not as easy as formulating a state regulation. It is because ageism lives, grows and develops massively in people's mindset, behaviour, and culture. Among the efforts that have been done to combat ageism, one of them is the official law formulated and issued by United States government. This law prohibits employers from discriminating against older workers and it was signed in 1967. However, this law, called Age Discrimination in Employment Act (ADEA), is often disobeyed by people and ageism keeps happening and developing in society (Jojonomic,1967).

Until now, there is no standard strategy or method to solve the problems regarding ageism. In July 2017, WHO (World Health Organization) initiated a meeting with researchers from universities in some countries to study about the effective method to overcome ageism. Here are some strategies that can be applied to combat ageism: 1) activating and strengthening positive stereotype about ageing; 2) involving social media, TV, movie, and companies that produce greeting cards to use and campaign positive sides of aging; 3) changing social norm developing; 4) issuing law or regulation of age discrimination; 5) developing and conducting some activities that involve various generations; and 6) doing campaign on social media (WHO, 2018)

Manifesting the 6 points above is not easy. Researchers believe that to change people's perspective of elderly needs massive and systemic efforts. One of strategic media is to through Educational Institution. 66\% respondents state that the most appropriate subject to foster and develop affection and social supports to elderly and to combat ageism, is civic education. Based upon this, this study proposes a new idea that is using civic education as an instrument to combat ageism.

\subsection{Where Is the Position of Civic Education in Preventing and Combating Ageism?}

One of learning subjects that is internationally regulated and managed by UNESCO is Global Civic Education that aims at transforming and building knowledge, skills, values or norms, and attitudes that must be learned by students to be able to contribute to the more inclusive, fair and peaceful world (UNESCO, 2015). Civic education uses a multi-faceted approach with concept and methodology that have been implemented in other fields including human right education, peace education, education for sustainable development, and education for international understanding, to proceed the common goals of the global community. The global civic education stands on a lifelong learning perspective starting from early childhood to all levels of education that needs formal and informal approaches, the interventions of curricular and extracurricular, and conventional and unconventional participation (UNESCO 2014, Global citizenship education: Preparing learners for the challenges of the 21 st century).

The global civic education aims at developing the values of justice and social justice, and constructing the skill to critically analyse the inequalities or discrimination towards gender, social-economy status, culture, religion, age, and other issues. This purpose explicitly explains that UNESCO as World Education Agency strongly concerns on the values of justice and equality in life context that is more inclusive and complex. 'Age' becomes the focus of discussion under the shelter of the equality issue held by UNESO through Global Civic Education. 
The concept of Global Civic Education believes that none of the countries in this world can overcome its problem by itself. To solve this problem, it demands collective efforts with synergy and cooperation with other countries in this world. Global interdependency is an undeniable concept for every country (Wahab \& Sapriya, 2011). To construct global perspective, global education needs to be incorporated into civic education in every country. "Age" should become global issue to construct a just and equal life. It becomes a fundamental meaning, considering the number of population in the entire world that keeps growing. The results of a study conducted by ORB-Media in 2018 reveal that the level of respect of a country to elderly will strongly impacts on the elderly welfare.

\subsection{Focus}

This study focuses on how to against ageism through civic education in the entire world as a form of contribution to solve the problems related to elderly. The aspect of ageism discussed in this study is the phenomena of ageism against elderly population.

\section{Research Methodology}

To answer the formulated research questions, a phenomenology study with constructivist paradigm was accomplished (Denzin dan Lincoln,2009). This approach was used to analyse the data gathered in depth. To collect the data needed, there were 43 informants who consisted of elderly and key informants from various institutions that focus on elderly services, both from governmental institutions and private institutions. The data were gathered by interviewing the informants who have sufficient knowledge and understanding about elderly service and by observing the elderly behaviours in social home care or in other public places. To strengthen the result of this study, a survey to 466 consisting of high school students and college students was also conducted to picture their individual perception on the problem that this study focused on (Creswell, 2015:753). Phenomenology study is used to identify and analyse in depth the data gathered from the interview and observation. The data analysis was accomplished based on the interactive model analysis developed by Miles and Huberman (1992). This model has some stages starting from data reduction, data display and conclusion drawing.

\section{Findings and Discussion}

\subsection{Young People's Perception to Elderly}

As a systematic and massive understanding, ageism is manifested by other populations to elderly in various forms, namely cognitive, behaviors and attitude starting form discriminatory mindset, ignorance, and even obvious social rejection. This notion has been supported by numerous research results. Referring to the survey result conducted to 466 young people (high-school students and college students) as the respondents, $61.4 \%$ of them state that elderly is a population who need to be cared for because of their weaknesses such as suffering from physical diseases due to their weak physical condition because of aging.

\section{Elderly is a population who need to be cared for 466 Respondents}

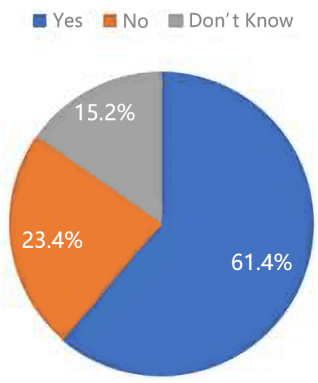

Source : Yasnita (2019)

As a result, the respondents, young people claim that it is better for elderly to stay at home and rest. Besides, young people are also skeptical about elderly because they think that elderly often underestimate them as they are lack of experience. This perception is pictured in the diagram of the survey result below.

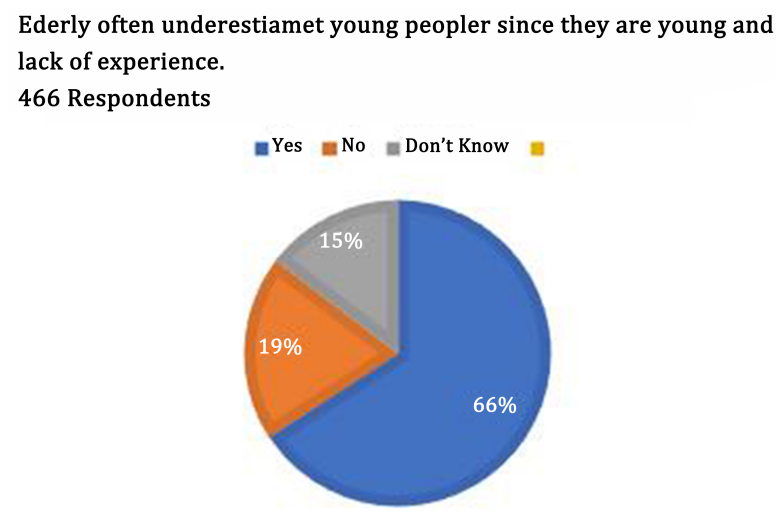

Source: Yasnita (2019)

This distrust has impacted on the communication gap between young people and elderly; therefore, 53\% respondents claim that they do not discuss, share or ask for advices from elderly (grandparents).

\subsection{Elderly's Perception on Themselves (Elderly's Self-Perception)}

Social views given by society towards elderly have impacted on their perceptions on themselves. Referring to the interview results to 32 informants consisting of elderly, the data show that: 
Table 1. Elderly's Perception on Their Existence

\begin{tabular}{|c|c|c|c|c|}
\hline No & Informant & Elderly's Perception on their Existence & Source of Revenue & Hope \\
\hline 1 & SL (P) 72 y.o & $\begin{array}{l}\text { Elderly should be independent, active, and not bother their } \\
\text { children. }\end{array}$ & $\begin{array}{l}\text { House rental (boarding } \\
\text { room rental) }\end{array}$ & \multirow{32}{*}{$\begin{array}{l}\text { Elderly want to be } \\
\text { humanized and } \\
\text { listened } \\
\text { To have activities that } \\
\text { could make them feel } \\
\text { meaningful and } \\
\text { empowered } \\
\text { To have source of } \\
\text { revenue to get income } \\
\text { for life. }\end{array}$} \\
\hline 2 & MI (L) 75 y.o & $\begin{array}{l}\text { Old age is a stage for enjoying lives, having activity and } \\
\text { doing interaction with society especially friends. }\end{array}$ & $\begin{array}{l}\text { Retirement salary and } \\
\text { house rental (boarding } \\
\text { room rental) }\end{array}$ & \\
\hline 3 & $\mathrm{SD}(\mathrm{L}) 70$ y.o & $\begin{array}{l}\text { Old age is a useless period, just need to wait for the time of } \\
\text { death. }\end{array}$ & $\begin{array}{l}\text { Mercy of children and } \\
\text { neighbours }\end{array}$ & \\
\hline 4 & SJ (L) 80 th & Old age is a problematic period, but we have to surrender & Selling in a small shop & \\
\hline 5 & UP (P) 70 y.o & $\begin{array}{l}\text { Feeling lonely without any friends and living a complicated } \\
\text { life. }\end{array}$ & Mercy of others & \\
\hline 6 & NR (P) 70 y.o & $\begin{array}{l}\text { The older our life is, the more complicated and hurtful it is, } \\
\text { and the sicker we are. }\end{array}$ & Mercy of others & \\
\hline 7 & LH (P) 64 y.o & $\begin{array}{l}\text { In the old age, we need to do what we think we can do for } \\
\text { grandchildren, neighbours and family. }\end{array}$ & Retirement salary & \\
\hline 8 & ET (L) 85 y.o. & $\begin{array}{l}\text { Be enthusiastic, active, and do not think of what other } \\
\text { people think and say about us. }\end{array}$ & $\begin{array}{l}\text { Cleaning tomb and } \\
\text { expecting mercy of } \\
\text { others. }\end{array}$ & \\
\hline 9 & $\begin{array}{l}\text { AT (L) } 78 \\
\text { y.o. }\end{array}$ & $\begin{array}{l}\text { Elderly should be wise, not feel lonely because we still have } \\
\text { our children and siblings. }\end{array}$ & Fulfilled by children & \\
\hline 10 & $\begin{array}{l}\text { YN (P) } 72 \\
\text { y.o. }\end{array}$ & $\begin{array}{l}\text { Old age is a period to enjoy life, be happy, and get closer to } \\
\text { God. }\end{array}$ & Retirement salary & \\
\hline 11 & SG (L) 75 y.o. & Be enthusiastic, active, happy and keep smiling & Selling newspapers & \\
\hline 12 & $\begin{array}{l}\text { WS (P) } 64 \\
\text { y.o. }\end{array}$ & $\begin{array}{l}\text { Old age is a complicated age, we just need to accept } \\
\text { everything given and happened, and wait for the death time. }\end{array}$ & Social Home Care & \\
\hline 13 & ID (P) 61 y.o. & $\begin{array}{l}\text { I feel like I am not a human, being neglected, but Social } \\
\text { home care makes me feel alive and treats me as human. }\end{array}$ & Social Home Care & \\
\hline 14 & YS (L) 60 y.o. & $\begin{array}{l}\text { I feel like I am not a human, being neglected, but Social } \\
\text { home care makes me feel alive and treats me as human. }\end{array}$ & Social Home Care & \\
\hline 15 & $\begin{array}{l}\text { BY (L) } 60 \\
\text { y.o. }\end{array}$ & $\begin{array}{l}\text { I feel like I am not a human, being neglected, but Social } \\
\text { home care makes me feel alive and treats me as human }\end{array}$ & Social Home Care & \\
\hline 16 & $\begin{array}{l}\text { IGA (P) } 60 \\
\text { y.o. }\end{array}$ & $\begin{array}{l}\text { Old age should be lived with high spirit, motivation and } \\
\text { happiness. }\end{array}$ & Social Home Care & \\
\hline 17 & JN (P) 63 y.o. & Old age is a period to contribute to society or community. & Retirement salary & \\
\hline 18 & SB (P) 63 у.о. & $\begin{array}{l}\text { Old age is a complicated period because in this age I have to } \\
\text { keep working. }\end{array}$ & $\begin{array}{l}\text { Massage therapist and } \\
\text { retirement salary of } \\
\text { her husband. }\end{array}$ & \\
\hline 19 & ZN (P) 63 y.o. & Old age is a heavy life, without any meaningful activities. & Fulfilled by children & \\
\hline 20 & SN (P) 70 y.o. & $\begin{array}{l}\text { Although we are old, we have to be independent and we } \\
\text { should not depend our life and needs on others. }\end{array}$ & $\begin{array}{l}\text { Selling foods (snack, } \\
\text { cakes, cookies, etc) }\end{array}$ & \\
\hline 21 & PS (L) 73 y.o. & Old age is difficult, I have no activity. & Shop rental & \\
\hline 22 & TS (P) 64 y.o. & $\begin{array}{l}\text { Old age is a period to complete our mission and obligation, } \\
\text { and enjoy life. }\end{array}$ & Retirement salary & \\
\hline 23 & JL(P) 78 y.o. & $\begin{array}{l}\text { Old age should be enjoyed and fulfilled with meaningful } \\
\text { activities and worship. }\end{array}$ & Retirement salary & \\
\hline 24 & ES (L) 77 y.o. & $\begin{array}{l}\text { Old age should be enjoyed and we should spend it by } \\
\text { sharing kindess. }\end{array}$ & $\begin{array}{l}\text { Retirement salary and } \\
\text { fulfilled by children. }\end{array}$ & \\
\hline 25 & SR (P) 72 y.o. & $\begin{array}{l}\text { Old age is a difficult time when we feel lonely, and separate } \\
\text { from children. }\end{array}$ & Fulfilled by children. & \\
\hline 26 & ST (P) 71 y.o. & In the old age we should keep on our spirit and be thankful. & Selling foods & \\
\hline 27 & $\begin{array}{c}\text { EM (P) } 72 \\
\text { y.o. }\end{array}$ & $\begin{array}{l}\text { Old age is a stage to enjoy life, keep being active and } \\
\text { enthusiastic, and be independent. }\end{array}$ & Retirement salary & \\
\hline 28 & AS (P) 52 y.o. & $\begin{array}{l}\text { Old age is a time when we are strongly respected and } \\
\text { glorified. }\end{array}$ & Civil servant & \\
\hline 29 & $\begin{array}{c}\mathrm{AM}(\mathrm{P}) 35 \\
\text { y.o }\end{array}$ & In the old age, we should be independent. & Tour Guide & \\
\hline 30 & $\begin{array}{l}\text { ON (P) } 76 \\
\text { y.o. }\end{array}$ & $\begin{array}{l}\text { Old age is a difficult period of life, yet, we have to } \\
\text { surrender. }\end{array}$ & Selling fruits & \\
\hline 31 & SN (P) 72 y.o. & $\begin{array}{l}\text { Old age is a difficult period, we have to struggle and survive } \\
\text { for children and grandchildren. }\end{array}$ & Selling vegetables & \\
\hline 32 & $\begin{array}{l}\text { AG (P) } 73 \\
\text { y.o. }\end{array}$ & $\begin{array}{l}\text { In this age, I want to be happy and enjoy my life with } \\
\text { various activities. hidup dengan berbagai aktivitas }\end{array}$ & Fulfilled by children. & \\
\hline
\end{tabular}

Source : Extracted from Yasnita's study (2019) 
14 informants claimed that old age is a difficult stage of life when they feel lonely, neglected, and do not humanized, and just depend on others' mercy such as children, family and neighbours. Meanwhile, 18 informants stated that old age should be enjoyed, filled with meaningful activities that they think they can do and fill it with happiness. They also said that in this age they have to be independent and enjoy the life without depending on others including children, as presented in the table below:

Table 2. Classification of Elderly Self Perception

\begin{tabular}{|c|c|}
\hline Perception & Number \\
\hline $\begin{array}{c}\text { old age is a difficult stage of life when they feel lonely, } \\
\text { neglected, and do not humanized, and just depend on } \\
\text { others' mercy such as children, family and neighbours. }\end{array}$ & 14 \\
\hline $\begin{array}{c}\text { old age should be enjoyed, filled with meaningful } \\
\text { activities that they think they can do, with happiness } \\
\text { and independence. }\end{array}$ & 18 \\
\hline
\end{tabular}

Source : Yasnita (2019)

Elderly population assume that old age is a difficult and complicated period, in which elderly are neglected by their family. Based on the observations conducted in several Social Home Cares and on the road, the informants stated that they are disappointed with their family. This feeling triggers them to feel sad and sorrowful. While, the informants assuming that old age should be enjoyed, are the elderly who have daily activities and are economically independent. This finding indicates that elderly social construction build by society has impacted on the development of their negative self-perception. Meanwhile, for elderly who enjoy their life, it is assumed that they enjoy their life more because they do not depend on their family and neighbours.

\section{Discussion}

In his explanation, Butler states that ageism systematically embedded and can affect people's objectivity and influence the decision making at various levels of society, namely micro level (individual or family), meso (organization or community) or macro (government or community). The cycle of ageism effects synthesized, extracted and formulated from Butler thought is presented as follows

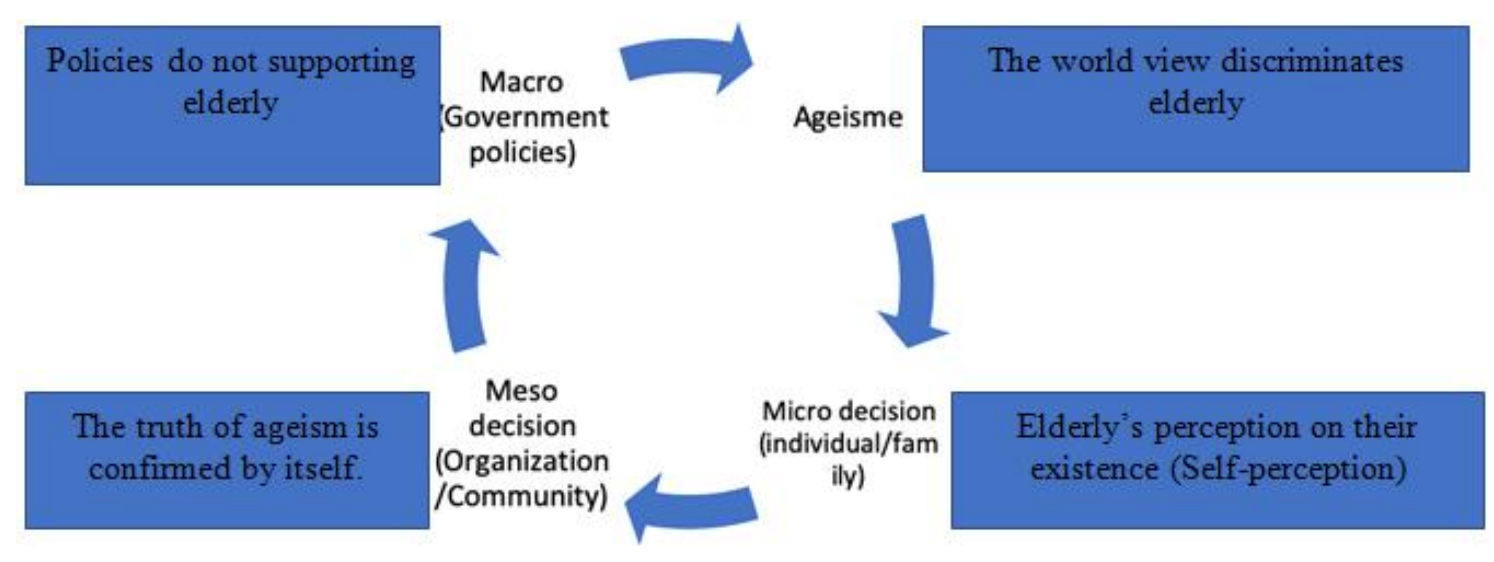

Source: Yasnita (2019)

Figure 2. The Cycle of Ageism Effects (Extracted and formulated from Butler, 1969) 
In social reality, ageism seems to be believed as a set of norms intertwined with human life and cultures.

Martin and Nakayam (2003:157) affirm that age identity becomes a special topic in intercultural communication because it has impacted on the relation of intercultural communication that is socially constructed. Every age group has its own characteristics. Age is a multi-perspective notion. Some people feel old when they are 30 years old, yet, some others still feel young when they are 40 or 50 years old. Martin and Nakayam (2003) also define that one's perception of their age changes by his or her age increases. For example, when people are in high school, they will think that college students are old; but, on the other hand, the college students still feel young. Martin and Nakayam (2003) also state that ageism against elderly is focused on the physical weaknesses and diseases suffered by the elderly. The statement saying that elderly is weak and not productive, is supported by several research findings such as a research conducted by Torrey (1992) that revealed that almost $25 \%$ elderly living in Social Home Care face difficulties in performing their activities. The elderly also feel difficult to take care of themselves (Manton\&Soldo,1992).

Loneliness experienced by elderly is the impact of withdrawing themselves from society (disengagement theory), as proposed by Cumming and Henry (1961) in Santrock (20012: 239). This is a cause-effect phenomenon where it is not only elderly who withdraw themselves from society but the society also does not want to engage with elderly. This disengagement theory is rejected by some studies (Maddox, 1968; Neugarten, Huvighurst \& Tobin, 1968; Reichard, Levson \& Peterson, 1962) that reveal that when an individual live actively, productively and enthusiastically, when they get old, their life satisfaction will not decrease, and even sometimes, it keeps increasing. Being an active, productive, and enthusiastic elderly is not easy, it demands social supports from society and world. Therefore, the social world view that has developed and lived in society needs to be reconstructed, a Social Reconstruction Syndrome (Kuypers \& Bengston, 1973).
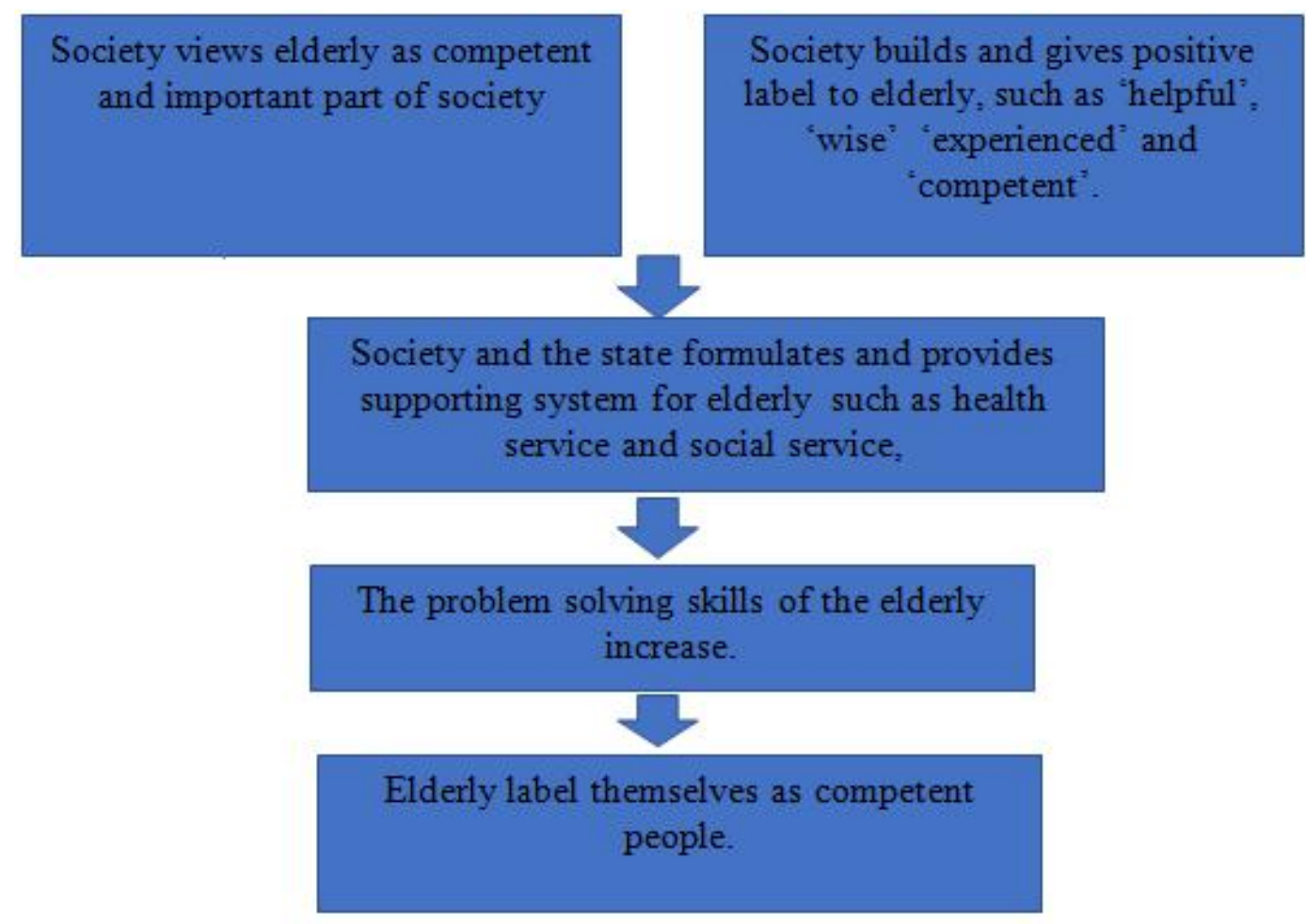

Source : Santrock (2002:240)

Figure 3. The Reconstruction of the Meaning of Elderly (Kuypers \& Bengston, 1973) 
Kuypers and Benston believe that society could view elderly as an important and competent population and build positive label to them such as 'helpful', 'wise' 'experienced' and 'competent'. The development of positive label can be supported by the existence of health and social services. Conducive environment can also help the problem-solving skills of the elderly increase, and one day, they will be able to build a positive label to themselves and believe that they are competent.

To change the view of the society that seems to be a social norm, is not easy. It requires consistency, commitment, and massive and systematic strategies. Therefore, there are some alternatives that can be manifested to cope with this issue including through Civic Education. Civic Education aims at developing the values of justice and social justice, and constructing the critical skill to analyse the inequalities or discrimination against gender, social-economy status, culture, religion, age, and other issues (UNESCO, 2015:15).

\subsection{What Can Civic Education Do?}

Civic education can play its strategic roles through social philanthropy movement in society (citizenship education). Through school curriculum, civic education curriculum can be incorporated with the elderly service issue that is focused on how young people love, respect, glorify and construct their new perception (anti-ageism) on elderly. Referring to the data gathered, $66 \%$ respondents believed that civic education is the most appropriate subject to be used as a medium to socialize and transform virtue or moral values towards elderly. UNESCO defines that this subject aims at developing the values of justice and social justice, and constructing the critical skill to analyse the inequalities or discrimination against gender, social-economy status, culture, religion, age, and other issues (UNESCO, 2015:15). As it is $n$ line with the core of this subject, the material about elderly service can be incorporated into some aspects, namely socio-emotional and behavioral aspects, as presented in the table below:

Table 3. The Incorporation of the Material about Elderly Service into Civic Education Curriculum

\begin{tabular}{|c|l|c|}
\hline Aspect & \multicolumn{1}{|c|}{ Approach } & Focus \\
\hline Cognitive & $\begin{array}{l}\text { To instil the mindset that every } \\
\text { human will be an elderly, and all } \\
\text { elderly are competent, wise and } \\
\text { experienced people. }\end{array}$ & $\begin{array}{c}\text { Civic } \\
\text { Education }\end{array}$ \\
\hline Socio-Emotional & $\begin{array}{l}\text { To have compassion, humanity } \\
\text { and respect for elderly. }\end{array}$ & $\begin{array}{c}\text { Civic } \\
\text { Education }\end{array}$ \\
\hline Behavioural & $\begin{array}{l}\text { To do direct actions showing } \\
\text { respect to the elderly, such as } \\
\text { visiting Social Home Care, being } \\
\text { a good listener to the elderly and } \\
\text { doing other social movements. }\end{array}$ & $\begin{array}{c}\text { Citizenshi } \\
\text { Education }\end{array}$ \\
\hline
\end{tabular}

Source: Yasnita (2019)

It becomes important and significant intervention considering the increment of elderly population in the world. Civic education plays its important roles to prepare the citizens to face their old age. Some Social Home Cares that became the site of this study have suggested to educate children (students) to love and respect elderly. This attitude has significant effects on elderly welfare and happiness.

ORB-Media, a linguistic institution in Washington DC in 2018 accomplished a study to 159.428 respondents in 102 countries to discover how respectful citizens are to elderly in the state. The study proves that: 1) The more respectful citizens are to elderly, the lower the chance of the elderly to live in poverty is; 2) The more respectful citizens are to elderly, the higher level of the elderly's welfare is; and 3) The more respectful citizens are to elderly, the better the quality of the elderly's physical health is (ORB Media-Tempo.Co, 2018). Previously, in 1982, Segerberg completed research on over 100-year-old elderly. The reasons behind their long lives are because of their family support and their social environment (Santrock, 2002, p. 193). Based upon this, anti-ageism is recommended to be one of issues to be discussed and developed in civic education and to be inclusive education program plan.

\section{Implication and Conclusions}

This study tries to strengthen and enrich the literatures related to elderly issues. Besides, this study also tries to offer a solution to solve the problem of discrimination against elderly (agism) and to prepare citizens to face their old age in the future. A systemic and massive approach through educational institution is one of alternatives to construct and increase respect for the elderly, which can affect the improvement of the elderly's health quality and welfare. Some literatures and research findings have revealed the correlation between respect and elderly's welfare. Global Civic Education is recommended as a subject to incorporate the material about elderly, as UNESCO states that one of the aims of this subject is to develop the values of justice and social justice, and constructing the skill to critically analyse the inequalities or discrimination towards gender, social-economy status, culture, religion, age, and other issues. Ageism is one of problems faced by all countries in the world. To build global perspective, the Global Civic Education material needs to be incorporated into local civic education in every country. Anti-ageism is recommended to be one of issues to be discussed and developed in civic education and to be inclusive education program plan.

\section{Acknowledgements}

There are many people who have contributed in accomplishing this study and this article, starting from the 
process of supervision to the process of writing this article. Therefore, I would like to deliver my highest appreciation, thanks, and gratitude to Prof.Dr. Karim Suryadi, M.Si., Prof. Dr. Dasim Budimansyah, M.Si., and Prof.Dr. Udin S Winataputra, MA., who have been very helpful, kind and patient in giving me advices, guidance, assistance, insights, moral support, and their valuable time during the process of accomplishing this study so that this article could be accomplished and published.

\section{REFERENCES}

[1] Butler, R. N. (1969, Desember 01). Age-ism : Another form of bigotry. The Gerontologist, 9(4 Part 1), 243-246.

[2] Creswell, J. (2015). Riset Pendidikan (Vol. 5). (H. P. Soetjipto, \& S. M. Soetjipto, Eds.) Yogyakarta, DIY, Indonesia: Pustaka Pelajar.

[3] Denzin, N. K., \& Lincoln, Y. S. (2009). Handbook of Qualitative Research (Vol. 1). (Dariyatno, B. S. Fata, Abi, \& J. Rinaldi, Eds.) Yogyakarta, DIY, Indonesia: Pustaka Pelajar.

[4] International, H. A. (2015). Ageing in The Twenty-First Century : A Celebration and A Challenge. Help Age International, Population Ageing. New York: United Nations.

[5] Jojonomic. (2019, October 24). Fenomena Diskriminasi Usia. (A. Haryanto, Producer, \& Jojonomic) Retrieved December 2019, from Jojonomic.com: https://jojonomic.com/blog/fenomena-diskriminasi-usia/

[6] Kelchner, E. S. (2000, October 20). Ageism'S Impact and Effect on Society. Journal of Gerontological Social Work, 32(4), 85-100.

[7] Lyons, A., Alba, B., Heywood, W., Fileborn, B., Minichiello, V., \& Barrett, C. (2017, July 28). Experiences of Ageism and the Mental Health of Older Adults. Aging \& Mental Health, 22(11), 1456 - 1464.

[8] Nainggolan, S. (2018, Juny 08). medcom. (-, Producer, \& -) Retrieved Oktober 2019, from www.medcom.id: http://www.medcom.id/rona/kesehatan/dN6Ea6RK-studimilenial-benci-dengan-istilah penuaan

[9] ORB Media-Tempo.Co. (2018, Juny 12). Menghadapi Penuaan Populasi. (O. Media, Producer, \& Tempo.Co) Retrieved 1 October 2019, from investigasi.tempo.co: http://investigasi.tempo.co/menghadapi-penuaan-populasi/

[10] Robertson, G. (2017, July 06). Ageing and Ageism: the impact of stereotypical attitudes on personal health and well-being outcomes and possible personal compensation strategies. Self \& Society An International Journal for Humanistic Psychology, 45(2), 149-159.

[11] Santrock, J. W. (2002). Life-Span Development Perkembangan Masa Hidup (Vol. 5). (W. C. Kristiaji, \& Y. Sumiharti, Eds.) Jakarta: Erlangga.

[12] Snellman, F. (2016, January 13). Whose ageism? The reinvigoration and definitions of an elusive concept.
Nordic Pscyhology, 68(3), 148-159.

[13] UNESCO. (2015). Global Citizenship Education TOPICS AND LEARNING OBJECTIVES. Fontenoy, Paris, France: United Nations Educational, Scientific and Cultural Organization,.

[14] Wahab, A. A., \& Sapriya. (2011). Teori dan LAndasan Pendidikan Kewarganegaraan. (Riduwan, \& A. Rohmiyati, Eds.) Bandung, Jawa-Barat, Indonesia: Alfabeta.

[15] WHO. (2018, Maret 09). A global campaign to combat ageism. (A. Officer, Producer, \& Departement of Aging and Life Course) Retrieved December 2019, from WHO.Int: http://www.unce.org

[16] Yasnita, Y. (2019). Konstruksi Makna Lansia dan Pemenuhan Hak-Hak Sebagai Warga Negara (Studi Fenomenologi Dalam Perspektif Pendidikan Kewarganegaraan) (Vol. Disertasi). (K. Suryadi, D. Budimansyah, \& U. S. Winataputra, Eds.) Bandung, Jawa Barat, Indonesia: Universitas Pendidikan Indonesia. 